\title{
Rapeseed meal as a protein source for growing pigs
}

\author{
MAIJA-LIISA SALO \\ Department of Animal Husbandry, University of Helsinki, 00710 Helsinki \\ 71, Finland
}

\begin{abstract}
Three groups of 17 Yorkshire pigs, from 24 to $98 \mathrm{~kg}$ liveweight, were fed on three diets which differed only in the main protein sources. Diet 1 contained Span rapeseed meal (RSM) $17 \%$ and pea $5 \%$, diet 2 RSM $8 \%$ and fish meal $4 \%$, and diet 3 (control) soybean meal (SBM) $5.5 \%$ and fish meal $4 \%$. The daily rations were isoenergetic and isonitrogenous, and contained digestive crude protein (DCP), lysine and S-amino acids according to standards. The feeds were steam pelleted, and the pigs were fed using a one-diet system and restrictive feeding.

The only clear difference between diets was the poorer palatability of those containing RSM, especially of diet 2. The feeding of groups 1 and 2 was therefore actually unrestrictive. The average daily intake of f.u./pig was significantly $(\mathrm{P}<0.01)$ lower in group 2 . Some tail biting occurred in group 2 .

The growth results were equal for diets 1 and 3 , and nonsignificantly poorer for diet 2 . The average daily gains of groups 1,2 and 3 were 813,788 and $820 \mathrm{~g}$, and the f.u./kg gain 2.74, 2.78 and 2.74, respectively. In carcass characteristics there were no differences between diets: the side fat was 20.3, 21.3 and $20.9 \mathrm{~mm}$, and the area of $l$. dorsi $36.7,37.8$ and $37.7 \mathrm{~cm}^{2}$, respectively. No odd tastes in fat or meat were observed.

The results indicate that quite a high level of Span RCM in steam pelleted diet can be fed and still produce high daily gain. The combination of RCM with other feed ingredients seems to have an extra influence on the palatability and nutritive value of the diet. Because RSM makes the diet more bulky and less palatable, the pigs can be fed ad libitum without negative effect on the carcass quality.
\end{abstract}

\section{Introduction}

The production of protein feeds in Finland is severely restricted by the climate. Some cultivars of rape (Brassica campestris mainly) thrive well, and rapeseed meal (RSM) is finding increased acceptance as a protein source for livestock. At present RSM is derived mainly from the high glucosinolate cultivars Span and Torch.

RSM has proven to be a useful protein source for ruminants. Even high glucosinolate (HG) meal has been fed with good results for growing bulls and high yielding dairy cows (IWARSSON et al. 1973, SHARMA et al. 1977, SYRJÄLÄ-QVIST et al. 1982). With pigs more caution is necessary. Many experiments have shown, however, that a good part of soybean meal (SBM) can be replaced with low glucosinolate (LG) RSM in the diet of growing pigs without adverse effect on the growth results (McKINNON and BOWLAND 
1977, KENDALL 1977, ALAVIUHKOLA 1981, NARENDRAN et al. 1981). The partial substitution of HG RSM for SBM has also been found to have no significant effect on the performance of growing pigs (BAILEY et al. 1969, PARTANEN 1975). B. campestris meal (cv. Span) is better than B. napus meal (cv. Target), which contains more oxazolidinethionine (CASTELL and MALLARD 1974). The nutritive value of Span RSM for pigs is about $35 \%$ below that of SBM (SALO 1982).

The objective of the present experiment was to study the use of commercial Span rapeseed meal in two different combinations in the diets of growing-finishing pigs. The daily rations were isoenergetic and isonitrogenous with the control diet containing soybean meal and fish meal as protein source.

\section{Material and methods}

Fifty-one Yorkshire pigs from five litters, average weight $21 \mathrm{~kg}$, were divided on the basis of sex and weight into three identical groups and each of them further into four subgroups. Each subgroup was then assigned at random to one of 12 pens. The pens were identical in size, concrete-floored without straw, and equipped with trough and self-waterer.

The pigs were fed with a one-diet system. The transition period was one week, after which the experimental period lasted until 95-102 kg liveweight. A vermicide was administered before the trial. The experiment was carried out in winter (November 1981-February 1982), and therefore the environmental temperature was only $14-18^{\circ} \mathrm{C}$.

All three diets included the same basic components: barley, milled using a $3 \mathrm{~mm}$ sieve, small amounts of domestic protein feeds, and mineral and vitamin supplements according to standards. The main protein sources differed. Diet 1 was supplied solely with domestic commercial RSM and pea, and the two others differed in that the SBM of the control (diet 3) was replaced with RSM in diet 2 (Tables 1, 2 and 3). The diets were formulated to contain the same amount of digestible crude protein (DCP), lysine, and

Table 1. Chemical composition and calculated nutritive value of ingredients of diets.

\begin{tabular}{lcccccccc}
\hline & Moisture & $\begin{array}{c}\text { Crude } \\
\text { protein } \\
\%\end{array}$ & $\begin{array}{c}\text { Ether } \\
\text { extract } \\
\%\end{array}$ & $\begin{array}{c}\text { Crude } \\
\text { fibre } \\
\%\end{array}$ & $\begin{array}{c}\text { N-free } \\
\text { extract } \\
\%\end{array}$ & $\begin{array}{c}\text { Ash } \\
\text { Kg/f.u. }\end{array}$ & DCP \\
\hline Barley meal & 14 & 10.7 & 1.8 & 5.1 & 66.0 & 2.4 & 0.96 & 83 \\
Skim milk powder & 6 & 32.7 & 0.5 & - & 52.4 & 8.4 & 1.15 & 311 \\
Meat and bone meal & 9 & 39.5 & 4.1 & - & 4.4 & 43.0 & 0.60 & 323 \\
Bacterial product & 8 & 68.5 & 6.8 & 1.3 & 11.4 & 4.0 & 0.80 & 361 \\
Soybean meal & 12 & 42.4 & 0.9 & 6.5 & 32.4 & 5.8 & 0.98 & 380 \\
Fish meal & 7 & 69.3 & 9.0 & - & 4.0 & 10.7 & 1.20 & 647 \\
Rapeseed meal & 12 & 32.2 & 4.3 & 13.1 & 31.3 & 7.1 & 0.72 & 231 \\
Pea meal & 15 & 24.0 & 1.6 & 6.5 & 49.8 & 3.1 & 0.96 & 202 \\
\hline
\end{tabular}


Table 2. Diet formulation and calculated nutritive value of diets.

\begin{tabular}{lccc}
\hline & \multicolumn{2}{c}{ Experimental diets } & Control \\
& 1 & 2 & 3 \\
\hline Ingredients, \% & & & 84.0 \\
Barley meal & 71.5 & 81.5 & 1.5 \\
Skim milk powder & 1.5 & 1.5 & 2.0 \\
Meat and bone meal & 2.0 & 2.0 & 1.0 \\
Bacterial product & 1.0 & 1.0 & 5.5 \\
Soybean meal & - & - & 4.0 \\
Fish meal & - & 4.0 & - \\
Rapeseed meal & 17.0 & 8.0 & - \\
Pea meal & 5.0 & - & 2.0 \\
Mineral and vitamin suppl. & 2.0 & 2.0 & 100.0 \\
\cline { 2 - 2 } & 100.0 & 100.0 & 1.05 \\
Kg feed (86 \% DM)/f.u. & 1.11 & 1.07 & 139 \\
DCP, g/f.u. & 138 & 137 & 8.8 \\
Lysine, g/f.u. & 9.3 & 9.0 & 6.1 \\
Methionine + cystine, g/f.u. & 6.2 & 6.2 & \\
\hline
\end{tabular}

Table 3. Average composition of diets by analysis.

\begin{tabular}{|c|c|c|c|}
\hline & \multicolumn{2}{|c|}{ Experimental diets } & \multirow{2}{*}{$\begin{array}{c}\text { Control } \\
3\end{array}$} \\
\hline & 1 & 2 & \\
\hline Moisture, \% & 85.5 & 85.9 & 85.8 \\
\hline \multicolumn{4}{|c|}{ Composition, $\%$ of dry matter } \\
\hline Crude protein & 19.3 & 18.7 & 18.8 \\
\hline Ether extract & 2.6 & 2.8 & 2.7 \\
\hline Crude fibre & 7.3 & 6.4 & 5.3 \\
\hline $\mathrm{N}$-free extract & 64.7 & 66.7 & 67.8 \\
\hline Ash & 6.1 & 5.4 & 5.4 \\
\hline \multicolumn{4}{|c|}{ Essential amino acids, $\mathrm{g} / \mathrm{kg}$ diet } \\
\hline Lysine & 9.4 & 8.0 & 7.9 \\
\hline Methionine & 2.1 & 2.2 & 2.1 \\
\hline Cystine & 2.5 & 2.4 & 2.4 \\
\hline Threonine & 5.0 & 5.0 & 5.4 \\
\hline Leucine & 10.6 & 10.5 & 10.7 \\
\hline Isoleucine & 5.8 & 5.6 & 5.8 \\
\hline Phenylalanine & 7.2 & 7.1 & 7.3 \\
\hline Valine & 7.1 & 7.4 & 6.8 \\
\hline Arginine & 8.0 & 6.9 & 6.7 \\
\hline Histidine & 4.3 & 3.8 & 3.9 \\
\hline \multicolumn{4}{|l|}{ Minerals/kg diet } \\
\hline $\mathrm{Ca} \quad \mathrm{g} / \mathrm{kg}$ & 9.4 & 9.0 & 7.9 \\
\hline $\mathrm{P} \quad$ & 7.7 & 7.3 & 7.1 \\
\hline $\mathrm{Mg}$. & 2.1 & 1.6 & 1.6 \\
\hline $\mathrm{Na}$ & 1.6 & 1.2 & 2.2 \\
\hline $\mathrm{K} \quad$ & 6.6 & 6.2 & 6.5 \\
\hline$\dot{\mathrm{Fe}} \quad \mathrm{mg} / \mathrm{kg}$ & 180 & 136 & 193 \\
\hline $\mathrm{Cu}$, & 92 & 52 & 145 \\
\hline $\mathrm{Zn}$ & 94 & 59 & 112 \\
\hline $\mathrm{Mn}$ & 47 & 31 & 45 \\
\hline
\end{tabular}


methionine + cystine per feed unit (f.u. $=0.7 \mathrm{~kg}$ starch equivalent). All groups thus received the same daily amount of net energy (f.u.), DCP, lysine and S-amino-acids (Table 2). The feeds were steam-pelleted and given dry. The pigs were fed twice daily on a restricted energy standard scale based on liveweight (PARTANEN 1970).

Feed consumption on pen basis was recorded daily, and the body weight individually every other week. After the first pigs reached the slaughter weight, the weight was checked weekly and those pigs weighing at least $95 \mathrm{~kg}$ were sent to the slaughter-house. At slaughter the carcass quality was determined by a measuring and dissecting technique.

The feed analyses were made according to standard procedures (Tables 1 and 3), and the f.u. and DCP values of the diets were calculated on the basis of the analyzed composition of the ingredients. The amino acids were determined with a Technicon amino acid analyzer. In the determination of cystine a proceding oxidation was used. The cations were determined with an atomic absorption spectrophotometer (Varian Techtron AA 1000) and phosphorus by the method of TAUSSKY and SHORR (1953). Glucosinolates were determined by the method of HEANEY and FENWICK (1980). The taste of fat and lean meat was judged by a panel of 15 persons. The results were tested by one- way variance analysis and the differences between means by the Tukeytest (STEELE and TORRIE 1960).

\section{Results and discussion}

It was expected that diet 1 with its $17 \%$ RSM would be the poorest one, but the praxis revealed that diet 1 was equal to the control, and diet 2 was worse (Fig. 1). The daily gain of group 2 was lower from the very beginning, and after six weeks the intake of diet 2 was impaired so much that the weekly increase of rations had to be slowed up from the normal scale. Consequently the average experimental period of group 2 lasted longer, and the feed intake (f.u./d) was significantly lower $(\mathrm{P}<0.01)$. The differences in the average daily gain and feed efficiency were, however, not significantly $(P>0.05)$ worse (Table 4).

The inferiority of diet 2 was manifested also as tail biting, which required an occasional division of one subgroup into two parts, and a penicillin cure for one pig. In other respects the state of health was good and no animal had to be removed from the groups. Two pigs suffered from leg weakness at the end of the period, both from the control group, and a slight PSE fault was indicated for one pig from both experimental groups. The diets probably had no share in these troubles since the supply of minerals (Table 3) satisfied or exceeded the common standards (ANON. 1981). Moreover, RSM has not been shown to affect the incidence of PSE (AHERNE et al. 1980). The weight of thyroid glands was no evaluated, because many investigators have already shown that RSM leads to the enlargement of thyroid gland (e.g. IWARSSON et al. 1973, McKINNON and BOWLAND 1979, ALAVIUHKOLA 1981).

No differences between groups were found in the carcass measurements 


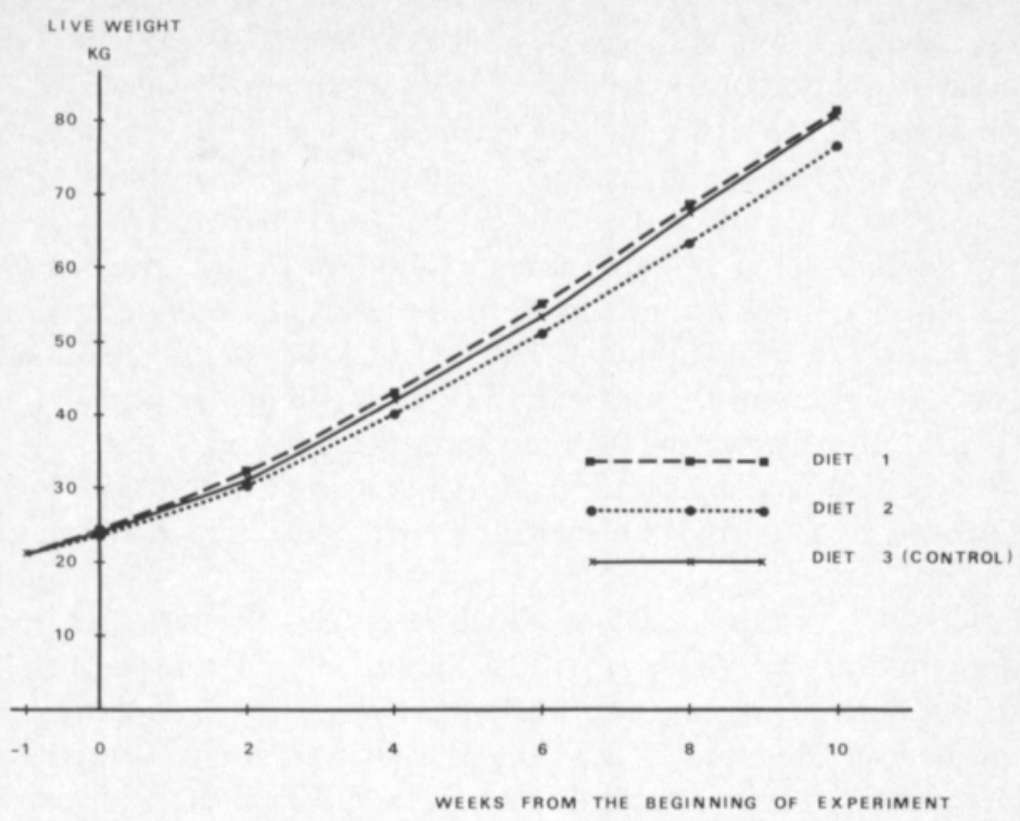

Figure 1. Growth rates of pigs.

Table 4. Effect of diet on the average growth results and carcass quality of pigs.

\begin{tabular}{llcc}
\hline & \multicolumn{2}{c}{ Experimental diets } & Control \\
& 1 & 2 & 3 \\
\hline Number of pigs & 17 & 17 & 17 \\
Initial weight, kg & 24.6 & 24.1 & 24.5 \\
Final weight, kg ${ }^{1}$ ) & 97.4 & 98.8 & 97.8 \\
Experimental days & 89.9 & 95.2 & 89.9 \\
Daily gain, g & 813 & 788 & 820 \\
Feed intake, f.u./ ${ }^{2}$ ) & $2.23^{\mathrm{c}}$ & $2.19^{\mathrm{d}}$ & $2.25^{\mathrm{c}}$ \\
F.u./kg gain & 2.74 & 2.78 & 2.74 \\
Dressing percentage & 73.8 & 74.3 & 75.1 \\
Side fat, mm & 20.3 & 21.3 & 20.9 \\
Area of l.dorsi, $\mathrm{cm}^{2}$ & 36.7 & 37.8 & 37.7 \\
Meat in valuable cuts, $\%$ & 78.6 & 78.0 & 77.9 \\
\hline
\end{tabular}

Significance: $P<0.05=a b, P<0.01=c d$

1) Corrected according to average dressing percentage of the groups.

$\left.{ }^{2}\right)$ f.u. $=$ feed unit $=0.7 \mathrm{~kg}$ starch equivalent.

(Table 4). The side- and backfat were rather thick, and the feed efficiency (f.u./kg gain) consequently rather poor, revealing that slaughtering at $90 \mathrm{~kg}$ liveweight would have been better than the used $98 \mathrm{~kg}$, especially for barrows. The carcass parameters were equal between groups, however, indicating that the lysine of the present RSM was sufficiently available. The analyzed lysine content of diet 1 was higher than that of the calculated value and therefore higher than that of the other diets (Tables 1 and 3). All diets 
included adequate lysine and other essential amino acids (ANON. 1981).

The glucosinolate content of the present Span RSM was $1.6 \%$ of dry matter $(37 \mu \mathrm{mol} . / \mathrm{g} \mathrm{DM}$, of which progoitrone $13 \mu \mathrm{mol} . / \mathrm{g})$. That value does not reveal the amount of glucosinolate components hydrolyzed in the seed pressing process. It is indicated, however, that the HG B. campestris cultivars contain lower amounts of glucosinolates, and especially their most goitrogenic component oxazolidinethione, than the HG B. napus cultivars (BELL and JEFFERS 1976). According to SAUER et al. (1982) the glucosinolate level of RSM has no effect on the utilization of amino acids by pigs.

The colour of meat and the firmness of fat were found to lie in the normal range and be equal in the various groups. Likewise, no odd taste or taint of fish was observed in fat or lean meat, nor were any differences noted between groups.

The diets were steam pelleted, which has been shown to improve the palatability and the feed/gain ratio, the beneficial effect being greater on RSM diets than on corn-SBM diets (NARENDRAN et al. 1979). The present RSM diets were nevertheless clearly less palatable than the control diet. The pigs ate diet 1 according to the standard scale, but not diet 2: the poor palatability resulted in a maximum daily ration of $2.6 \mathrm{f}$.u./pig, although the control group had eaten more.

There was also a distinct difference between the groups in their eating pattern. Whereas the control group ate the ration in less than half an hour, the RSM groups consumed their feed throughout the day. They also spilled out and wasted some feed on the floor on the pens, and the true amount of feed consumed was slightly smaller than that of the control group and what the figures of Table 4 show. Nevertheless the final growth results of group 1 and the control group were identical. The present results suggest that slow eating may have a beneficial effect on the utilization of feed: when the feed is eaten in small portions throughout the day, a greater portion of it can be digested and absorbed before reaching the large intestine, where the digestion is carried out by bacteria and is more wasteful. A slightly reduced palatability could thus be beneficial. And such a diet can be fed without restriction, which actually was the case with the present diets 1 and 2 . The explanation of IWARSSON et al. (1973) for the good growth result of bulls fed on a high level of commercial RDM was a slightly lowered metabolic rate, because they found slightly lowered thyroid function in bulls fed RSM.

The present experiment showed that the combination of a high level of HG RSM with another protein source may have an influence on the palatability and nutritive value of diets. Diet 2 (8\% RSM $+4 \%$ fish meal) would seem to be better than diet 1 (17\% RSM $+5 \%$ pea), but the judgement of the pigs was the reverse. In the control diet, however, the pigs willingly ate the same fish meal in combination with SRM. It remained unclear why the pigs appreciated the combination of RSM and pea more than the combination of RSM and fish meal.

In conclusion, the present results indicate that quite a high level of Span RSM in steam pelleted feed can be fed to growing-finishing pigs and still produce an average $800 \mathrm{~g}$ daily gain. The low net energy and DCP values of 
RSM (about $35 \%$ below those of SBM) must be taken into consideration in calculating the nutritive value of the diets. The combination of RSM with other feed ingredients seems to have an extra influence on the palatability and nutritive value of diets. Because RSM makes the diet more bulky and less palatable, the pigs can be fed ad libitum without negative effect on the carcass quality.

Acknowledgements: I wish to express my thanks to the Vaasa Mills Ltd. for preparing the experimental feeds and contributing a part of them, and to Mrs. Anneli Pakarinen for technical help.

\section{References}

AHERNE, F. X., CHOVELON, A. M., HAWRYSH, Z. J. \& PRICE, M. A. 1980. The effects of canola and rapeseed supplemented diets on swine performance, pork colour and $\mathrm{pH}$ of pork. Canola Council of Canada, Publ. 57: 172-176.

ALAVIUHKOLA, T. 1981. Rypsijauho lihasikojen rehuseoksissa. Koetoiminta ja käytäntö 2/1982: 7. ANON. 1981. The nutrient requirements of pigs. 307 p. England.

BAILEY, H. S., CHO, C. Y. \& SUMMERS, J. D. 1969. Growth and digestibility studies to evaluate rapeseed meal as a protein supplement for swine. Can. J. Anim. Sci. 49: 367-373.

BELL, J. M. \& JEFFERS, H. F. 1976. Variability in the chemical composition of rapeseed meal. Can. J. Anim. Sci. 56: 269-273.

CASTELL, A. G. \& MALLARD, T. M. 1974. Utilization of ground seed or meal from low erucic acid rape (Brassica campestris cv. Span) in diets for growing-finishing pigs. Can. J. Anim. Sci. 54: $443-454$.

HEANEY, R. K. \& FENWICK, G. R. 1980. The analysis of glucosinolates in Brassica species using gas chromatography. Direct determination of the thiocyanate ion precursors, glucobrassicin and neoglucobrassicin. J. Sci. Food Agric. 31: 593-599.

IWARSSON, K., EKMAN, L., EVERITT, B. R., FIGUEIRAS, H. \& NILSSON, P. O. 1973. The effect of feeding rapeseed meal on thyroid function and morphology in growing bulls. Acta vet. scand. 14: 610-629.

KENDALL, J. D. 1977. Nutritive value of Tower rapeseed meal. Feedstuffs 49, No 37: 12.

McKINNON, P. J. \& BOWLAND, J. P. 1977. Comparison of low glucosinolate - low erucic acid rapeseed meal (cv. Tower), commercial rapeseed meal and soybean meal as sources of protein for starting, growing and finishing pigs and young rats. Can. J. Anim. Sci. 57: 663-678.

McKINNON, P. J. \& BOWLAND, J. P. 1979. Effects of feeding low and high glucosinolate rapeseed meals and soybean meal on thyroid function of young pigs. Can. J. Anim. Sci. 59: 589-596.

NARENDRAN, R., BOWMAN, G. H., LEESON, S. \& PFEIFFER, W. 1981. Effect of different levels of Tower rapeseed meal in corn-soybean meal based diets on growing-finishing pig performance. Can. J. Anim. Sci. 61: 213-216.

NARENDRAN, R., BOWMAN, G. H. \& SLINGER, S. J. 1979. Effect of steam pelleting diets containing two varieties of rapeseed meal on pig performance. Can. J. Anim. Sci. 59: 577-583.

PARTANEN, J. 1970. Lihasikojen uudet viikottaiset ry-normit. Sika 4/1970: 6-18.

PARTANEN, J. 1975. Rypsirouheet lihasikojen valkuaisrehuna. Koetoiminta ja käytäntö 10: 35-36.

SALO, M.-L. 1982. Nutritive value of rapeseed meals and cakes for pigs and sheep. J. Scient. Agric. Soc. Finl. 54: 305-312.

SAUER, W. C., CICHON, R. \& MISIR, R. 1982. Amino acid availability and protein quality of canola and rapeseed meal for pigs and rats. J. Anim. Sci. 54: 292-301.

SHARMA, H. R., INGALLS, J. R. \& McKIRDY, J. A. 1977. Effects of feeding a high level of Tower rapeseed meal in dairy rations on feed intake and milk production. Can. J. Anim. Sci. 57: 653-662.

STEELE, R. G. D. \& TORRIE, J. H. 1960. Principles and procedures of statistics. 481 p. New York. 
SYRJÄLÄ-QVIST, L, TUORI, M. \& SETÄLÄ, J. 1982. Rapeseed meal as a protein source for highproduction dairy cows on grass silage and hay-based feeling. J. Scient. Agric. Soc. Finl. 54: $145-153$.

TAUSSKY, H. H. \& SHORR, E. 1953. A microcolorimetric method for the determination of inorganic phosphorus. J. Biol. Chem. 202: 675-685.

Ms received September 23, 1982.

\section{SELOSTUS}

\section{Rypsirouhe lihasikojen rehuna}

\section{Maija-Liisa Salo}

\section{Helsingin yliopiston kotieläintieteen laitos, 00710 Helsinki 71}

Kolme 17 yorkshiresian ryhmää ruokittiin $24-98 \mathrm{~kg}$ :n painoväli rehuseoksilla, jotka poikkesivat toisistaan vain päävalkuaisrehun osalta. Koeryhmän 1 rehussa oli kotimaista kaupallista rypsirouhetta $17 \%$ ja hernettä $5 \%$. Koeryhmän 2 rypsirouhetta $8 \%$ ja kalajauhoa $4 \%$ ja vertailuryhmän (ryhmä 3 ) soijarouhetta $5.5 \%$ kalajauhoa $4 \%$. Rehut oli rakeistettu ja siat ruokittiin yhden rehun järjestelmällä Partasen normien mukaan. Kaikki ryhmät saivat päivittäin saman ry- ja srv-määrän. Rehuseokset sisälsivät srv, lysiiniä, rikkipitoisia aminohappoja, kivennäisiä ja vitamïneja normien mukaisesti. Täyttävyys nousi rypsirouhemäärän mukana.

Ainoa selvä ero koetuloksissa oli rypsiä sisältävien seosten huonompi maittavuus, erityisesti seos 2 kelpasi sioille heikonlaisesti. Ryhmät 1 ja 2 saivat sen vuoksi rehua itse asiassa vapaasti. Päivittäin syöty ry-määrä jäi ryhmällä 2 muita merkitsevästi alemmaksi $(P<0.01)$. Ryhmällä 2 esiintyi myös jonkin verran hännänpurentaa, mutta muuta mainittavaa sairautta sioilla ei ilmennyt.

Päiväkasvu ja rehun hyötysuhde oli koeryhmällä 1 samaa tasoa kuin vertailuryhmällä, ryhmällä 2 heikompi, joskaan ero ei ollut merkitsevä. Keskimääräiset päiväkasvut ryhmillä 1,2 ja 3 olivat 813,788 ja $820 \mathrm{~g}$ ja hyötysuhteet $2.74,2.78$ ja 2.74 ry $/ \mathrm{kg}$ lisäkasvua. Ruhon laadussa ei ollut eroa: kylkisilavamitat olivat $20.3,21.3$ ja $20.9 \mathrm{~mm}$ ja pitkän selkälihaksen mitat 36.7 , 37.8 ja $37.7 \mathrm{~cm}^{2}$. Mitään sivumakua ei todettu silavassa eikä lihassa.

Koe osoitti, että ainakin rakeistettuna ja tiettynä yhdistelmänä kotimaista kaupallista rypsirouhetta voidaan lihasioille syöttää varsin suurena väkevyytenä ja silti päästä $800 \mathrm{~g}: \mathrm{n}$ päiväkasvuun. Rehuyhdistelmällä näyttää olevan vaikutusta maittavuuteen. Koska runsas rypsirouheen käyttö tekee rehun täyttävämmäksi ja huonommin maittavaksi, rehua voidaan sioille antaa vapaasti ilman että ruhon laatu kärsii. Seosten rehuarvoa laskettaessa on huomioitava, että rypsirouheen ry- ja srv-arvot ovat sialla noin $35 \%$ soijarouheen arvoja alemmat. 